\title{
Yaşlı Turistlerin Otel İşletmelerinde Önem Verdiği Ürün ve Hizmetler: Alman, İngiliz ve Hollandalı Turistlere Yönelik Bir Karşılaştırma
}

The Products and Services That Senior Tourists Give Importance at the Hotel Enterprises: A Comparison of German, British and Dutch Tourists

\author{
Tahir ALBAYRAK*, Meltem CABER ${ }^{* *}$, Müjde BíDECi*** \\ * Yrd. Doç. Dr., Akdeniz Üniversitesi, Turizm Fakültesi, Dumlupınar Bulvarı, Kampüs, 07058, Antalya. \\ E-posta: tahiralbayrak@akdeniz.edu.tr \\ ** Doç. Dr, Akdeniz Üniversitesi, Turizm Fakültesi, Dumlupınar Bulvarı, Kampüs, 07058, Antalya. \\ E-posta: meltemcaber@akdeniz.edu.tr \\ *** Arş. Gör., Akdeniz Üniversitesi, Turizm Fakültesi, Dumlupınar Bulvarı, Kampüs, 07058, Antalya. \\ E-posta:mujdebideci@gmail.com
}

\section{MAKALE BILGILERI \\ Makale işlem bilgileri: \\ Gönderilme tarihi: 26 Haziran 2013 \\ Birinci değerlendirme: 1 Ağustos 2013 \\ İkinci değerlendirme: 27 Ağustos 2013 \\ Üçüncü değerlendirme: 10 Ekim 2013 \\ Kabul: 16 Ekim 2013 \\ Anahtar sözcükler: \\ Yaşl turist, Otel, Ürün, Hizmet.}

\section{öz}

Dünya nüfusu içindeki payları ve satınalma güçleri giderek artan yaşılıar, turizm sektörü açısından önemli bir pazar bölümü haline gelmiștir. Günümüzde yaşlı turistler, kendilerinden önceki nesillere kıyasla daha aktif; yaşam kaliteleri ve tüketici bilinci daha yüksek kişilerdir. Bu sebeple otel işletmeciliği gibi bünyesinde birçok ürün ve hizmeti barındıran işletmeler açısından bu pazar bölümünün özellikli istek ve beklentilerinin anlaşılabilmesi, müşteri memnuniyetinin sağlanabilmesi ve küresel rekabete cevap verilebilmesi için bir gerekliliktir. Bu çalışmada yaşlı turistlerin genel olarak otel işletmelerinde önem verdikleri ürün ve hizmetler, hem iki alt yaş grubuna (50-64 yaş arası, 65 yaş ve üzeri), hem de milliyete bağlı olarak karşılaştıııımıştır. Bu amaçla Antalya ilinde faaliyet gösteren beş yıldızlı otellerde konaklayan 1150 Alman, İngiliz ve Hollandalı yaşlı turistten veri toplanmıştır. Elde edilen sonuçlara göre, tüm yaș ve milliyet grupları için genel temizlik ile personelin tutum ve davranışları ile ilgili özellikler en fazla önem taşıyan hususlardır.

\section{ARTICLE INFO}

Article history:

Submitted: 26 June 2013

Resubmitted: 1 August 2013

Resubmitted: 27 August 2013

Resubmitted: 10 October 2013

Accepted: 16 October 2013

\section{Key words:}

Senior tourist, Hotel, Product, Service.

\begin{abstract}
Senior people, whose share in the world population and power of purchasing are gradually increasing, have become an important market segment for tourism sector. Nowadays, senior tourists are the people who more active than the generations before themselves; have higher quality of life and consumer awareness. Therefore, it is a need to understand the specific needs and expectations of this market segment for the enterprises such as hotels that contain many products and services inside of their structures, for achieving customer satisfaction and responding the global competition. In this study, hotel products and services that senior tourists generally give importance were compared both by two sub-age groups (between 50-64 years, 65 and above years) and nationality. With this purpose, data were obtained from 1150 German, British and Dutch senior tourists who had been accommodating at the five star hotels in Antalya. According the results, general cleanliness and the attributes related to staff attitude and behaviour are the most important factors for all age and nationality groups.
\end{abstract}

\section{GiRiş}

II. Dünya Savaşı sonrasında yaşanan teknolojik, ekonomik, politik ve kültürel gelişmeler, ülkelerin sosyo-demografik yapılarının değişmesine yol açmıştır. Özellikle gelişmiş ve gelişmekte olan ülkelerde ortalama yaşam süresi, kişi başına düşen milli gelir ve serbest zaman gibi konularda yaşanan artışla birlikte, hayat kalitesi de yükselmiştir. Bu bağlamda, "sağliklı yaşlanmaya" olanak bulan bireyler, ilerleyen yaşlarında da faal kalabilmişlerdir. Diğer taraftan, zamansal ve ekonomik kısıtları azalan yaşlı bireylerin turizme katılım motivasyonları ve seyahat etme alışkanlıkları değişmiştir (Śniadek 2006). Bu değişimler, turizm işletmeleri açısından yeni ve önemli bir pazar bölümünü ortaya çıkarmıştır. Diğer taraftan yaşlı nüfusun dikkat çekici 
artış oranı da yaşlı turist pazarının önemini arttırmaktadır. Nitekim Dünya Sağlık Örgütü (WHO 2013) öngörülerinde, 2000-2050 yılları arasında, dünya nüfusu içerisinde 60 yaş ve üzeri bireylerin payının \%11'den \%22 seviyesine çıkacağ 1 ifade edilmektedir. Aynı dönemde, bu yaş grubundaki bireylerin toplam sayısı 605 milyondan 2 milyara yükselecektir. Avrupa Birliği'ne üye ülkelerde ise 65 yaş üzeri nüfusun 2050 yılına kadar yaklaşık 40 milyon artması beklenmektedir (Seyhun 2006).

Yaşlı turist pazarının artan önemine karşılık, yaşlılık olgusunun tanımlanması konusunda akademik açıdan tam bir uzlaşı bulunmadığı görülmektedir. Yaşlılık olgusu, araştırma alanına bağlı olarak "ekonomik", "sosyal", "kronolojik", "biyolojik", "fizyolojik", "psikolojik" ve "toplumsal" yaşlılık olmak üzere farklı şekillerde tanımlanmaktadır (Güler 1998; Tümerdem 2006). “Takvim yaşı" nda dahi hangi yaş döneminin "yaşlılık" kapsamında ele alınması gerektiği hususunda genel bir kabul yoktur. Bazı araştırmacılara göre (Shoemaker 1989; Javalgi Thomas ve Rao 1992; Kotler, Bowen ve Makens 1996) 55 yaş ve üstü, bazı araştırmacılara göre (Lewis 1996; Silvers 1997) 50 yaş ve üstü bireyler "yaşlı" kategorisinde yer almalıdır. Yaşlıllk döneminin, belli yaş dönemlerine ayrılarak incelenmesi gerektiğini savunan araştırmacılar da bulunmaktadır. Örneğin, Hartman ve Qu (2007), ilgili dönemi kendi içinde yaşlılık öncesi (50-64 yaş arası) ve yaşlı (65 yaş ve üzeri) olarak iki bölümde ele almış, Riley ve Riley (1986) ise alt sınırı 65 yaş olarak belirleyerek, erken yaşlılar (65-74 yaş arası), orta yaşlılar (75-84 yaş arası) ve ileri yaşlılar ( 85 yaş ve üzeri) şeklinde gruplamıştır. Dünya Sağlık Örgütü ise 65 yaş ve üzeri bireyleri "yaşlı" olarak tanımlamaktadır. Mevcut alanyazındaki farklılıklar göz önüne alınarak, bu çalışmada geniş kapsamlı bir bakış açısıyla 50 yaş ve üzeri bireylerin yaşlılık döneminde bulundukları kabul edilmiştir.

Tanımlayıcı nitelikteki bu araştırmanın başlıca amac1, Antalya iline gelen Alman, İngiliz ve Hollandalı yaşlı turistlerin demografik özelliklerinin tespit edilmesini takiben, genel olarak otel işletmelerinin kendilerine sunmuş olduğu çeşitli ürün ve hizmetlere verdikleri önemin ortaya konulmasıdır. Ayrıca turistlerin önem algıları hem milliyetleri göz önüne alınarak hem de Hartman ve Qu'nun (2007) önermiş olduğu iki yaş grubuna (50-64 yaş arası, 65 yaş ve üzeri) bağlı olarak karşılaştırılmış- tır. İlgili çalışma ile Antalya bölgesine gelen yabancı yaşlı turistlerin konaklama işletmelerindeki ürün ve hizmetlerden göreceli olarak hangilerine daha fazla önem verdikleri tespit edilerek, müşteri memnuniyetinin sağlanabilmesi için öncelik verilmesi gereken hususlar ortaya konmuştur.

\section{KAVRAMSAL ÇERÇEVE}

Yaşlı turistlerle ilgili alanyazında ele alınan başl1ca araştırma konuları arasında; pazar bölümlemesi (Littrell, Paige ve Song 2004), pazar yapısının kavramsal açıdan incelenmesi ve özel pazarlama yaklaşımları (Avcıkurt 2003; Hudson 2010; Mungall, Schegg ve Courvoisier 2010), yeme-içme tercihleri ve müşterilerin yeme-içme işletmelerini seçme kriterleri (Kim, Raab ve Bergman 2010; Kim, Bergman ve Raab 2010), restoran hizmet kalitesinden memnuniyet (Lee, Cho ve Ahn 2012), seyahat bilgi kaynaklarının önemi (Patterson 2007), seyahatten memnuniyet (Özdipçiner 2009; 2010), konaklama işletmesi seçim kriterleri (Chen, Liu ve Chang 2013), konaklama hizmetlerinden memnuniyet (Shortt ve Ruys 1994; Wei, Ruys ve Muller 1999; Callan ve Bowman 2000; Wuest, Emenheiser ve Tas 2001; Hartman ve Qu 2007), seyahat motivasyonu (Jang ve Wu 2006; Sangpikul 2008a; 2008b; Jang v.d. 2009; Esichaikul 2012; Alegre, Cladera ve Sard 2011), seyahate katılım kısitları (Fleischer ve Pizam 2002; Jang ve Ham 2009; Gram ve Smed 2011), seyahat-sağllk ilişkisi (Hunter-Jones ve Blackburn 2007), seyahat satın alma karar süreci ve seçim kriterleri (Horneman v.d. 2002; Reece 2004; Wang, Chen ve Chou 2007; Batra 2009; Schitko ve Losekoot 2012; Lee, Tsai ve Tsang 2012) yer almaktadır.

Otel işletmeciliği açısından yaşlı turistlerin önemini ortaya koyan ve bu pazarı daha yakından incelemeyi hedef edinen ilk çalışmalardan biri Shortt ve Ruys (1994) tarafından gerçekleştirilmiş olup, ilgili araştırmada yaşlı turistlerin otellerdeki güvenlik algıları ve tutumları arasındaki ilişki incelenmiştir. Daha sonra Wei, Ruys ve Muller (1999), üç ve beş yıldızlı otellerin pazarlama müdürleri ve yaşlı turistlerin otel özelliklerine yönelik alg1 farklilıklarını; Wuest, Emenheiser ve Tas (2001) ise otel yöneticileri ve yaşlı turistlerin otel özelliklerine yönelik algı farklılıklarını karşılaştırmıştır. Hartman ve Qu (2007) yaşlı turistlerin hizmet özellikleri, otel düzeni ve dizaynı ile ilgili önem algılarını inceleyerek; otel yöneticileri için doğru ve yanlış stratejileri belirlemeyi amaçlamıştır. 
Mevcut araştırmalar incelendiğinde, yaşlı turistlerin otel işletmelerinde en fazla önem verdikleri ürün ve hizmetleri tespit etmeyi amaçlayan araştırmaların kısıtlı sayıda olduğu görülmektedir. Marvel (1999) tarafından gerçekleştirilen ve yaşlı turistlere özel otel ürün ve hizmetlerinin incelendiği çalışmada, müşterilerin tanıtım materyallerinin, otel broşürlerinin, televizyon kılavuzlarının veya menülerin kolay okunabilir olması açısından daha büyük yazım formatlarının kullanılmasına önem verdikleri tespit edilmiştir. Chu ve Choi (2000), iş ve tatil amaçlı seyahat eden turistleri karşılaştırdıkları çalışmalarında, yatak ve yastık konforunun, oda temizliğinin ve oda sıcaklık kontrolünün müşteriler açısından önem taşıyan hususlar olduğunu ortaya koymuşlardır. Gustin ve Weaver'in (1993) 53 otel ürün ve hizmetinin yaşlı turistler açısından önemini araştırdığı çalışmada, temizlik, uygun konum, oda fiyatı, otele kolay ulaşım, güvenlik sistemi ve otopark aydınlatması otel seçiminde en önemli hususlar olarak tespit edilmiştir. Callan ve Bowman'ın (2000) 104 yaşlı İngiliz ile yaptığı çalışmada ise rekreasyon faaliyetlerinin göreceli olarak önemli olmadığı, buna karşılık çalışanların tutum ve davranışlarının önemli bulunduğu vurgulanmıştır. Ayrıca yazarlara göre cinsiyet, emeklilik durumu gibi kriterlere göre yaşlı turistlerin önem verdiği hususların farklılık göstermesi, yaşlı pazarının da kendi içinde heterojen bir yapıya sahip olduğunu göstermiştir. İlgili araştırmalar kısmen otel işletmelerinin ürün ve hizmetleri ve yaşlı turistlerin bu kapsamdaki tatmin ve beklentilerini ölçmeye dayalı araştırmalar olmasına karşın, bu araştırmalarda sadece bir pazarın incelenmiş olması ve pazar farklılıklarının ortaya konulmaması, başlıca eksiklikler olarak göze çarpmaktadır.

Türkiye'deki ilgili alanyazın incelendiğinde, yaşlı pazar bölümünü doğrudan hedef alan çalışmaların sınırlı sayıda olduğu görülmektedir. Örneğin Avcıkurt (2003) Avrupa'daki yaşlı turist pazarının boyutu ve önemi ile Türkiye ve dünya turizmi üzerine etkilerini; Özdipçiner $(2009 ; 2010)$ Bodrum'a gelen yaşlı Alman turistlerin hastalık ve çalışma durumlarının seyahat tatminleri üzerine etkisini incelemiştir. Türkiye'de yaşlı turistlerin otel işletmelerinde en fazla önem verdikleri ürün ve hizmetlerin belirlenmesine yönelik herhangi bir çalışmaya rastlanmamaktadır.

\section{YÖNTEM}

Alanyazın taraması sonucunda, yaşlı turistler için geliştirilmiş ve otellerdeki ürün ve hizmetlere ilişkin kapsamlı bir ölçek olması sebebiyle Callan ve Bowman'ın (2000) çalışmasında yer alan maddelerin kullanılmasına karar verilmiştir. Bu ölçekte yer alan maddelere (varsa) ilave edilmesi gereken hususları ve ölçeğin kapsam geçerliliğini tespit etmek maksadıyla 10 Alman, 6 Hollandalı ve 3 İngiliz yaşlı turist ile odak grup çalışması yapılmıştır. Odak grup katılımcılarından 38 maddeden oluşan ölçeğin anlaşılırlığını kontrol etmeleri istenmiştir. Daha sonra mevcut ölçek maddelerine ilave etmek istedikleri hususları belirtmeleri istenmiştir. Katılımcıların ilave herhangi bir husus önermemeleri nedeniyle, ölçeğin orijinal haliyle kullanılmasına karar verilmiştir. Anket katılımcılarının, otel işletmelerinin ürün ve hizmetlerine verdikleri önem 5 'li Likert (1: hiç önemli değil, 5: çok önemli) tipi ölçek ile tespit edilmiştir. Anketin son bölümünde, kat1lımcıların demografik özelliklerini ölçen dokuz soru ve seyahat tercihlerini ölçen yedi soru yer almıştır. Anket formunun orijinali İngilizce olduğundan İngiliz turistler için aynı şekilde uygulanmıştır. Anket Almanca diline profesyonel tercüman tarafından çevrildikten sonra, anadili Almanca olan otel rehberlerine kontrol ettirilmiştir. Hollandalıların İngilizce ya da Almanca dillerinden birine vakıf olmaları ve Flemenkçe bilen anketör bulma güçlüğü göz önüne alınarak, Hollandalı turistlerin İngilizce ya da Almanca anketlerden birini tercih etmeleri sağlanmiştır.

Örneklem hacminin belirlenmesinde oran yöntemi kullanılmıştır. Oran hesabında, Antalya iline gelen turistlerin yaş dağılımlarına ait veri bulunmaması sebebiyle, Türkiye'ye gelen turistlerin yaş dağılım verileri esas alınmıştır. Türkiye'ye 472.773 'ü 65 yaş ve üzeri olmak üzere toplam 3.625.603 (www.tuik.gov.tr 2010) Alman turist geldiği tespit edilmiş olduğundan, P oranı 0,13 olarak hesaplanmıştır. Araştırma için örnekleme hatası $\pm \%$, güven düzeyi ise $\% 95$ olarak belirlenmiştir. Buna göre Alman katılımcılar için örneklem hacmi 282 olarak tespit edilmiştir. Aynı hesaplama yöntemiyle, İngiliz (211.253'ü 65 yaş ve üzeri, toplam 2.131.481 turist) ve Hollandalı (45.478'i 65 yaş ve üzeri, toplam 824.741 turist) katılımcılar için örneklem hacmi s1rasıyla 216 ve 125 olarak belirlenmiştir. 50-64 yaş arası ile 65 yaş ve üzeri gruplar arasında karşılaştır- 
ma yapılabilmesi amacıyla her iki yaş grubundan da aynı miktarda örneklem alınması kararlaştırılmiştır.

Anketin uygulanacağ yonel Otel Yöneticileri Derneği (POYD) Yönetim Kurulu üyelerinin önerileri doğrultusunda kolayda örnekleme yöntemiyle belirlenmiştir. Buna göre Antalya ili Kundu mevkiinde ve Finike ilçesinde faaliyet gösteren toplam onüç adet beş yıldızlı otel işletmesi alan araştırmasına destek vermiştir. Alan araştırmasında yüksek lisans eğitimi almakta olan üç öğrenci anketör olarak görev almıştır. 10 Aralık 2011 ile 10 Nisan 2012 tarihleri arasında 1150 kişiye uygulanan anket aracilığı ile veri seti oluşturulmuş ve çözümleme bu veri seti üzerinden gerçekleştirilmiştir. Kullanılan ölçeğin Cronbach Alfa katsayısı
0,92 olduğundan ölçeğin güvenilir olduğu kabul edilmiştir. Araştırmaya dahil edilen otel işletmelerinin başlıca hedef pazarı Almanya olduğundan, iki yaş grubunda da hedeflenen Alman katılımcı sayısı sağlanmakla birlikte, 65 yaş ve üzeri İngiliz ve Hollandalı katılımcılarda hedef sayıların altında kalınmıştır. Bu durum araştırma açısından bir kısıt oluşturmaktadır.

\section{BULGULAR}

\section{Demografik Özellikler}

Katılımcıların demografik özellikleri ve seyahat tercihleri Tablo 1'de özet olarak gösterilmiştir. Bu çalışmaya katılan Alman turistlerin çoğunluğunu 50-64 yaş aralığında (\%46) özel sektör çalışanları, 65 ve üzeri yaş aralığında ise emekliler $(\% 84,4)$

Tablo 1. Katılımcıların Demografik Özellikleri

\begin{tabular}{|c|c|c|c|c|c|c|c|}
\hline & & \multicolumn{2}{|c|}{ Alman } & \multicolumn{2}{|c|}{ Ingiliz } & \multicolumn{2}{|c|}{ Hollandalı } \\
\hline & & $\begin{array}{l}65 \text { yaş } \\
\text { ve üzeri } \\
(n=277)\end{array}$ & $\begin{array}{r}50-64 \\
\text { yaş arası } \\
(n=353)\end{array}$ & $\begin{array}{c}65 \text { yaş } \\
\text { ve üzeri } \\
(n=119)\end{array}$ & $\begin{array}{r}50-64 \\
y a s ̧ \text { arası } \\
(n=223)\end{array}$ & $\begin{array}{c}65 \text { yaş } \\
\text { ve üzeri } \\
(n=58)\end{array}$ & $\begin{array}{r}50-64 \\
\text { yaş arası } \\
(n=120)\end{array}$ \\
\hline \multirow[t]{2}{*}{ Cinsiyet } & Erkek & 60,3 & 46,3 & 58,5 & 37,6 & 67,3 & 43,5 \\
\hline & Kadın & 39,7 & 53,7 & 41,5 & 62,4 & 32,7 & 56,5 \\
\hline \multirow[t]{2}{*}{ Medeni Durum } & Evli & 86,4 & 84,9 & 84,2 & 80,5 & 82,5 & 88,7 \\
\hline & Bekâr & 13,6 & 15,1 & 15,8 & 19,5 & 17,5 & 11,3 \\
\hline \multirow[t]{4}{*}{ Aylık Gelir } & $1000 €$ ve altı & 15,4 & 13,5 & 13,7 & 7,8 & 4,4 & 4,3 \\
\hline & $1001-2000 €$ & 32,8 & 30,1 & 39,7 & 31,7 & 24,4 & 20,9 \\
\hline & $2001-3000 €$ & 28,9 & 24,7 & 34,3 & 30,0 & 35,6 & 36,3 \\
\hline & $3000 €$ ve üzeri & 22,9 & 31,7 & 12,3 & 30,5 & 35,6 & 38,5 \\
\hline \multirow[t]{6}{*}{ Meslek } & Emekli & 84,4 & 20,7 & 88,3 & 32,3 & 81,9 & 19,6 \\
\hline & Kamu çalışanı & 4,7 & 7,8 & 0,8 & 14,0 & & 9,4 \\
\hline & Özel sektör çalışanı & 1,5 & 46,0 & 5,9 & 30,2 & & 26,5 \\
\hline & Ev hanımı & 1,8 & 9,8 & - & 4,1 & 3,6 & 10,3 \\
\hline & İşyeri sahibi & 4,7 & 10,2 & 2,5 & 6,8 & 1,8 & 17,1 \\
\hline & Diğer & 2,9 & 5,5 & 2,5 & 12,6 & 12,7 & 17,1 \\
\hline Türkiye'ye Geliş & İlk kez & 7,4 & 7,3 & 22,9 & 21,0 & 3,9 & 5,3 \\
\hline \multirow[t]{3}{*}{ Sayısı } & 2. kez & 8,2 & 11,1 & 20,3 & 22,8 & 5,9 & 4,4 \\
\hline & 3. kez & 6,3 & 11,4 & 16,9 & 16,9 & 11,8 & 7,9 \\
\hline & 4 ve üzeri kez & 78,1 & 70,2 & 39,8 & 39,3 & 78,4 & 82,4 \\
\hline \multirow[t]{3}{*}{ Konaklama Süresi } & 1-7 gün & 16,4 & 28,4 & 46,6 & 58,2 & 5,6 & 14,9 \\
\hline & 8-14 gün & 36,6 & 50,2 & 41,5 & 36,4 & 59,3 & 65,8 \\
\hline & 15 gün ve üzeri & 47,0 & 21,4 & 11,9 & 5,5 & 35,1 & 19,3 \\
\hline
\end{tabular}


oluşturmaktadır. 50-64 arası Alman katılımcıların $\% 31^{\prime} i 3000 €$ ve üzerinde aylık gelire sahipken, 65 yaş ve üzerinde bu oran $\% 22,9$ 'dur. Her iki yaş grubunda da Almanların \%70'inden fazlası Türkiye'ye 4 ve daha fazla kez gelmiştir. 50-64 yaş arası Almanlar 8-14 gün arası (\%50,2); 65 yaş ve üzeri Alman katılımcılar 15 gün ve üzeri tatil $(\% 47,0)$ süresini tercih etmektedir.

İngiliz katılımcıların çoğunluğunu her iki yaş grubunda da (50-64 yaş arası \%80,5; 65 yaş ve üzeri \%84,2) evli kişilerin oluşturduğu görülmektedir. Türkiye'ye 4 ve üzeri kez gelen İngiliz katılımcıların oranı her iki yaş grubunda da \%39 seviyesinde olup, Alman ve Hollandalı katılımcılara göre bu çok daha düşük bir orandır. 65 yaş ve üzeri katılımciların \%88,3'ü emeklilerden oluşurken, 50-64 yaş arası katılımcılarda bu oran daha düşüktür (\%32,3). 50-64 yaş arası katılımcıların \%30,5'i 3000 $€$ ve üzeri gelire sahip iken 65 yaş ve üzeri katılımcılarda aynı gelir seviyesine sahip olanların oranı nispeten düşüktür $(\% 12,3)$.

65 yaş ve üzeri Hollandalı katılımcıların çoğunluğunu $(\% 81,9)$ emekliler; 50-64 yaş arası katılımcıların \%26,5'ini ise özel sektör çalışanları oluşturmaktadır. Hollandalı katılımcların cinsiyet ve medeni durum dağılımları her iki yaş grubunda da diğer milliyetlerle benzerlik taşımasına karşılık, Türkiye'ye geliş sayıları ve konaklama sürelerindeki farklılıklar göze çarpmaktadır. Buna göre, 50-64 yaş arası Hollandalı katılımcıların 4 ve üzeri sayıda ülkeye geliş sayısı $(\% 82,4)$, diğer iki milliyete kıyasla daha yüksektir. Konaklama süreleri her iki yaş grubunda da 8-14 gün aralığında yoğunlaşmaktadır.

\section{Otel İşletmelerindeki Ürün ve Hizmetlere Verilen Önemin Tespiti (Milliyet ve Yaş Gruplarına Göre)}

Araştırmaya katılanlar 50-64 yaş arası; 65 yaş ve üzeri olmak üzere iki gruba ayrılarak, yaş gruplarının otel işletmelerindeki ürün ve hizmetlere verdikleri önem incelenmiştir. Alman katılımcılara ait sonuçlar Tablo 2'de gösterilmiştir.

Her iki yaş grubundaki Alman katılımcıların en fazla önem verdiği ilk beş ürün veya hizmetin dördü aynıdır. "Genel temizlik" iki yaş grubunun da en fazla önem verdiği husus iken bunu "personelin sicakkanlılığı" takip etmiştir. "Personelin kibarlığı" ve "açık büfe yiyecek çeşitliliği" iki yaş grubu için diğer önemli hususlardır. En önemli ilk on ürün veya hizmetten beşinin iki yaş grubunda da personel- le ilgili olması dikkate değer bir husustur. "Tesiste organize edilen eğlenceler", "özel diyet menüleri" ve "park yeri" ise iki yaş grubu için de en az öneme sahip hususlardır. İki yaş grubu arasında fark olup olmadığı bağımsız örneklem t-testi ile araştırılmıştır. Bu maksatla öncelikle ifade değerlerinin normal dağılıma sahip olduğu görsel olarak (Q-Q ve kutu bıyık grafikleri) tespit edilmiştir. Toplam 38 ürün ve hizmetin sadece sekizinde iki yaş grubu arasında istatistiki açıdan anlamlı farklılık mevcuttur. "Üst yaş gruplarına yönelik hizmetler", "sigara içilmeyen odalar", "erken saatte akşam yemeği olanağ1" ve "tesisin şöhreti" hususlarına 65 yaş ve üzeri Alman katılımcılar, 50-64 yaş arasındakilere göre daha fazla önem vermektedir.

İngiliz katılımcıların iki yaş grubu için de en fazla önem verdikleri husus "genel temizlik"tir. İkinci sırada "odaların rahatlığı" gelmektedir. 65 yaş ve üzeri İngilizler için daha sonra sırasıyla "personelin kibarlığı", "otelin bakım onarım standartları" ve "algılanan parasal değer"; 50-64 yaş arası İngilizler için "güvenlik ve koruma", "personelin kibarlı̆̆1" ve "personelin sicakkanlılı̆̆g" önem taş1maktadır. Her iki yaş grubu için en düşük öneme sahip dört husus ise "üst yaş gruplarına yönelik hizmetler", "jakuzi, sauna", "jimnastik" ve "park yeri" dir. 65 yaş ve üzeri İngiliz katılımcılarla 50-64 yaş arasındakilerin ürün ve hizmetlere vermiş oldukları önem bağımsız örneklem t-testi ile kıyaslandığında, değerlendirmeye konu olan 38 ürün ve hizmetten 17 'sinde istatistiki açıdan anlamlı farklılık bulunmuştur. 65 yaş ve üzerindeki İngiliz katılımcılar "üst yaş gruplarına yönelik hizmetler", "özel diyet menüler", "kolay okunabilir menü, işaret ve bilgiler" ve "otel etrafında kolayca gezinti imkanı"na, 50-64 yaş arasındakilere kıyasla daha fazla önem vermektedir. Aralarında istatistiki açıdan anlamlı farklılıklar olan diğer hususlar Tablo 3 'te gösterilmiştir.

65 yaş ve üzeri Hollandalı katılımcılar için otel işletmesi seçiminde "personelin sıcakkanlılığı" en önemli husus iken bunu sırasıyla "odaların rahatlığı" ve "sigara içilmeyen odalar" takip etmektedir (Tablo 4). 50-64 yaş aralığındaki Hollandalı katılımcılar için -65 yaş ve üzeri katılımcılara kıyasla"sigara içilmeyen odalar" önem açısından daha alt sıralarda yer almaktadır. Hollandalı katılımcıların yaş gruplarına göre otel işletmesi seçiminde önem verdikleri hususlar bağımsız örneklem t-testi ile karşılaştırıldığında, sadece 6 ürün ve hizmette ista- 
Tablo 2. Alman Katılımcların Yaş Gruplarına Göre Önem Farkları

\begin{tabular}{|c|c|c|c|c|c|c|c|}
\hline \multirow[b]{2}{*}{ Ürün ve Hizmetler } & \multicolumn{3}{|c|}{65 yaş ve üzeri $(n=277)$} & \multicolumn{3}{|c|}{ 50-64 yaş arası $(n=353)$} & \multirow[b]{2}{*}{$p$} \\
\hline & Ort. & Std.Sap. & ÖS & Ort. & Std.Sap. & Ös & \\
\hline Genel temizlik & 4,81 & 0,50 & 1 & 4,85 & 0,42 & 1 & 0,338 \\
\hline Personelin sıcakkanlılığı & 4,79 & 0,58 & 2 & 4,79 & 0,53 & 2 & 0,893 \\
\hline Personelin kibarlığı & 4,75 & 0,60 & 3 & 4,69 & 0,59 & 4 & 0,263 \\
\hline Açık büfe yiyecek çeşitliliği & 4,71 & 0,66 & 4 & 4,69 & 0,67 & 5 & 0,738 \\
\hline Güvenlik ve koruma & 4,71 & 0,61 & 5 & 4,59 & 0,67 & 8 & $0,029^{*}$ \\
\hline Personelin dikkati & 4,70 & 0,64 & 6 & 4,62 & 0,68 & 7 & 0,159 \\
\hline Personelin dış görünümü & 4,69 & 0,62 & 7 & 4,59 & 0,69 & 9 & 0,072 \\
\hline (algılanan) Parasal değer & 4,68 & 0,62 & 8 & 4,59 & 0,74 & 10 & 0,130 \\
\hline Personelin iş hevesi & 4,68 & 0,64 & 9 & 4,65 & 0,60 & 6 & 0,548 \\
\hline Odaların rahatığı & 4,66 & 0,63 & 10 & 4,71 & 0,56 & 3 & 0,335 \\
\hline Otelin genel atmosferi & 4,63 & 0,69 & 11 & 4,57 & 0,71 & 11 & 0,326 \\
\hline Odaların genişliği ve ferahlığı & 4,62 & 0,70 & 12 & 4,54 & 0,64 & 13 & 0,200 \\
\hline Otel etrafında kolayca gezinti imkânı & 4,59 & 0,68 & 13 & 4,54 & 0,72 & 14 & 0,371 \\
\hline Otelin bakım/onarım standartları & 4,59 & 0,63 & 14 & 4,54 & 0,68 & 15 & 0,441 \\
\hline Verilen siparişin beklenen şekilde edinimi & 4,58 & 0,69 & 15 & 4,57 & 0,61 & 12 & 0,907 \\
\hline Odaların dekoru & 4,54 & 0,75 & 16 & 4,48 & 0,68 & 19 & 0,318 \\
\hline Hizmetlerin yeterliliği & 4,54 & 0,71 & 17 & 4,49 & 0,69 & 17 & 0,372 \\
\hline Tesisin konumu & 4,54 & 0,77 & 18 & 4,44 & 0,82 & 20 & 0,153 \\
\hline Hizmetlerin sunum hızı & 4,51 & 0,76 & 19 & 4,49 & 0,63 & 18 & 0,776 \\
\hline Ortak alanların rahatlığı & 4,49 & 0,73 & 20 & 4,43 & 0,72 & 21 & 0,311 \\
\hline Uygulanan fiyat & 4,48 & 0,92 & 21 & 4,34 & 0,96 & 22 & 0,084 \\
\hline Ortak alanların dekoru & 4,43 & 0,75 & 22 & 4,33 & 0,74 & 23 & 0,108 \\
\hline Dinlendirici lobi ve bar(lar) & 4,37 & 0,94 & 23 & 4,54 & 0,68 & 16 & 0,016 \\
\hline İyi aydınlatılmış odalar & 4,35 & 0,89 & 24 & 4,21 & 1,01 & 25 & 0,079 \\
\hline Sigara içilmeyen odalar & 4,32 & 1,31 & 25 & 4,07 & 1,45 & 27 & $0,036^{*}$ \\
\hline Yüzme havuzu & 4,32 & 1,03 & 26 & 4,32 & 0,96 & 24 & 0,988 \\
\hline İyi aydınlatılmış ortak alanlar & 4,18 & 1,00 & 27 & 4,18 & 0,97 & 26 & 0,975 \\
\hline Kolay okunabilir menü, işaret ve bilgiler & 4,16 & 1,20 & 28 & 3,95 & 1,22 & 28 & $0,040^{*}$ \\
\hline İndirimler & 3,89 & 1,24 & 29 & 3,75 & 1,15 & 29 & 0,168 \\
\hline Tesisin şöhreti & 3,89 & 1,22 & 30 & 3,54 & 1,27 & 32 & $0,001^{\text {** }}$ \\
\hline Erken saatte akşam yemeği olanağı & 3,88 & 1,34 & 31 & 3,54 & 1,37 & 33 & $0,002^{* *}$ \\
\hline Üst yaş gruplarına yönelik hizmetler & 3,81 & 1,29 & 32 & 3,05 & 1,43 & 37 & $0,000^{* *}$ \\
\hline Jakuzi, sauna & 3,81 & 1,34 & 33 & 3,75 & 1,26 & 30 & 0,621 \\
\hline Küçük porsiyon yiyecek bulabilme olanağı & 3,69 & 1,40 & 34 & 3,53 & 1,34 & 34 & 0,173 \\
\hline Jimnastik & 3,68 & 1,37 & 35 & 3,67 & 1,27 & 31 & 0,958 \\
\hline Tesiste organize edilen eğlenceler & 3,53 & 1,43 & 36 & 3,12 & 1,45 & 36 & $0,001^{* *}$ \\
\hline Özel diyet menüleri & 3,35 & 1,56 & 37 & 3,14 & 1,55 & 35 & 0,120 \\
\hline Park yeri & 2,80 & 1,74 & 38 & 2,31 & 1,64 & 38 & $0,001^{* *}$ \\
\hline
\end{tabular}

${ }^{*} \mathrm{p}<0,05$; ${ }^{* *} \mathrm{p}<0,01$; ÖS: Önem Siras1 
Yaşlı Turistlerin Otel İşletmelerinde Önem Verdiği Ürün ve Hizmetler: Alman, İngiliz ve Hollandalı Turistlere Yönelik Bir Karşılaştırma

Tablo 3. İngiliz Katılımcıların Yaş Gruplarına Göre Önem Farkları

\begin{tabular}{|c|c|c|c|c|c|c|c|}
\hline \multirow[b]{2}{*}{ Ürün ve Hizmetler } & \multicolumn{3}{|c|}{65 yaş ve üzeri $(n=119)$} & \multicolumn{3}{|c|}{ 50-64 yaş arası $(n=223)$} & \multirow[b]{2}{*}{$p$} \\
\hline & Ort. & Std.Sap. & Ös & Ort. & Std.Sap. & Ös & \\
\hline Genel temizlik & 4,93 & 0,25 & 1 & 4,87 & 0,42 & 1 & 0,135 \\
\hline Odaların rahatığı & 4,86 & 0,34 & 2 & 4,81 & 0,46 & 2 & 0,238 \\
\hline Personelin kibarlığı & 4,86 & 0,39 & 3 & 4,77 & 0,56 & 4 & 0,106 \\
\hline Otelin bakım/onarım standartları & 4,83 & 0,42 & 4 & 4,62 & 0,74 & 15 & $0,001^{* *}$ \\
\hline (algılanan) Parasal değer & 4,82 & 0,44 & 5 & 4,70 & 0,56 & 6 & $0,038^{*}$ \\
\hline Personelin sıcakkanlılığı & 4,81 & 0,47 & 6 & 4,72 & 0,64 & 5 & 0,127 \\
\hline Güvenlik ve koruma & 4,80 & 0,48 & 7 & 4,78 & 0,55 & 3 & 0,787 \\
\hline Hizmetlerin yeterliliği & 4,79 & 0,48 & 8 & 4,65 & 0,64 & 12 & $0,022^{*}$ \\
\hline Personelin dikkati & 4,77 & 0,50 & 9 & 4,70 & 0,51 & 7 & 0,286 \\
\hline Hizmetlerin sunum hızı & 4,77 & 0,46 & 10 & 4,69 & 0,62 & 8 & 0,196 \\
\hline Personelin iş hevesi & 4,76 & 0,52 & 11 & 4,66 & 0,68 & 11 & 0,149 \\
\hline Verilen siparişin beklenen şekilde edinimi & 4,75 & 0,49 & 12 & 4,68 & 0,65 & 10 & 0,352 \\
\hline Personelin dış görünümü & 4,73 & 0,52 & 13 & 4,51 & 0,66 & 18 & $0,001^{* *}$ \\
\hline Tesisin şöhreti & 4,73 & 0,52 & 14 & 4,50 & 0,75 & 19 & $0,002^{* *}$ \\
\hline Ortak alanların rahatı̆̆ı & 4,72 & 0,50 & 15 & 4,69 & 0,58 & 9 & 0,608 \\
\hline Dinlendirici lobi ve bar(lar) & 4,69 & 0,64 & 16 & 4,63 & 0,66 & 13 & 0,374 \\
\hline Açık büfe yiyecek çeşitliliği & 4,65 & 0,66 & 17 & 4,63 & 0,66 & 14 & 0,798 \\
\hline Ortak alanların dekoru & 4,64 & 0,51 & 18 & 4,48 & 0,68 & 22 & $0,030^{*}$ \\
\hline İyi aydınlatılmış ortak alanlar & 4,63 & 0,73 & 19 & 4,45 & 0,75 & 23 & $0,040^{*}$ \\
\hline Odaların genişliği ve ferahlığı & 4,63 & 0,66 & 20 & 4,52 & 0,65 & 17 & 0,238 \\
\hline Otelin genel atmosferi & 4,61 & 0,66 & 21 & 4,50 & 0,75 & 20 & $0,004^{* *}$ \\
\hline Uygulanan fiyat & 4,59 & 0,91 & 22 & 4,49 & 0,85 & 21 & 0,357 \\
\hline Odaların dekoru & 4,58 & 0,59 & 23 & 4,41 & 0,77 & 24 & $0,030^{*}$ \\
\hline Otel etrafında kolayca gezinti imkânı & 4,54 & 0,73 & 24 & 4,15 & 0,99 & 28 & $0,000^{* *}$ \\
\hline İyi aydınlatılmış odalar & 4,52 & 0,76 & 25 & 4,30 & 0,86 & 26 & $0,029^{*}$ \\
\hline Tesisin konumu & 4,51 & 0,76 & 26 & 4,28 & 0,88 & 27 & $0,022^{*}$ \\
\hline Sigara içilmeyen odalar & 4,50 & 1,09 & 27 & 4,33 & 1,26 & 25 & 0,207 \\
\hline Yüzme havuzu & 4,46 & 1,06 & 28 & 4,58 & 0,79 & 16 & 0,311 \\
\hline Tesiste organize edilen eğlenceler & 4,19 & 1,19 & 29 & 3,95 & 1,21 & 29 & 0,092 \\
\hline Kolay okunabilir menü, işaret ve bilgiler & 4,14 & 1,01 & 30 & 3,76 & 1,17 & 31 & $0,004^{* *}$ \\
\hline İndirimler & 4,07 & 1,23 & 31 & 3,84 & 1,14 & 30 & 0,114 \\
\hline Erken saatte akşam yemeği olanağı & 3,95 & 1,11 & 32 & 3,71 & 1,17 & 32 & 0,083 \\
\hline Özel diyet menüleri & 3,79 & 1,41 & 33 & 3,36 & 1,44 & 33 & $0,018^{*}$ \\
\hline Küçük porsiyon yiyecek bulabilme olanağı & 3,59 & 1,42 & 34 & 3,33 & 1,36 & 34 & 0,129 \\
\hline Üst yaş gruplarına yönelik hizmetler & 3,58 & 1,32 & 35 & 3,12 & 1,34 & 36 & $0,004^{* *}$ \\
\hline Jakuzi, sauna & 3,46 & 1,41 & 36 & 3,19 & 1,38 & 35 & 0,120 \\
\hline Jimnastik & 3,13 & 1,53 & 37 & 2,68 & 1,38 & 37 & $0,019^{*}$ \\
\hline Park yeri & 2,99 & 1,77 & 38 & 2,02 & 1,45 & 38 & $0,000^{* *}$ \\
\hline
\end{tabular}

${ }^{*} \mathrm{p}<0,05 ;{ }^{* *} \mathrm{p}<0,01$; ÖS: Önem Siras1 
Tablo 4. Hollandalı Katılımcıların Yaş Gruplarına Göre Önem Farkları

\begin{tabular}{|c|c|c|c|c|c|c|c|}
\hline \multirow[b]{2}{*}{ Ürün ve Hizmetler } & \multicolumn{3}{|c|}{65 yaş ve üzeri $(n=58)$} & \multicolumn{3}{|c|}{$50-64$ yaş arası $(n=120)$} & \multirow[b]{2}{*}{$p$} \\
\hline & Ort. & Std.Sap. & ÖS & Ort. & Std.Sap. & ÖS & \\
\hline Personelin sıcakkanlılığı & 4,68 & 0,55 & 1 & 4,67 & 0,67 & 3 & 0,926 \\
\hline Odaların rahatlığı & 4,67 & 0,51 & 2 & 4,74 & 0,60 & 2 & 0,499 \\
\hline Sigara içilmeyen odalar & 4,61 & 0,80 & 3 & 4,48 & 1,03 & 13 & 0,427 \\
\hline Genel temizlik & 4,60 & 0,63 & 4 & 4,79 & 0,47 & 1 & 0,069 \\
\hline Hizmetlerin sunum hızı & 4,60 & 0,57 & 5 & 4,50 & 0,62 & 11 & 0,316 \\
\hline Güvenlik ve koruma & 4,59 & 0,64 & 6 & 4,55 & 0,73 & 7 & 0,747 \\
\hline Hizmetlerin yeterliliği & 4,58 & 0,53 & 7 & 4,55 & 0,63 & 8 & 0,760 \\
\hline Personelin kibarlığı & 4,58 & 0,57 & 8 & 4,60 & 0,64 & 5 & 0,824 \\
\hline Personelin iş hevesi & 4,58 & 0,57 & 9 & 4,61 & 0,58 & 4 & 0,780 \\
\hline Otelin bakım/onarım standartları & 4,57 & 0,54 & 10 & 4,46 & 0,71 & 14 & 0,309 \\
\hline Personelin dikkati & 4,54 & 0,64 & 11 & 4,44 & 0,70 & 15 & 0,395 \\
\hline Tesisin şöhreti & 4,53 & 0,61 & 12 & 4,27 & 0,93 & 25 & $0,039^{*}$ \\
\hline Verilen siparişin beklenen şekilde edinimi & 4,53 & 0,66 & 13 & 4,58 & 0,68 & 6 & 0,675 \\
\hline Otelin genel atmosferi & 4,44 & 0,73 & 14 & 4,42 & 0,73 & 16 & 0,895 \\
\hline Personelin dış görünümü & 4,43 & 0,64 & 15 & 4,40 & 0,76 & 18 & 0,800 \\
\hline Ortak alanların rahatlığı & 4,43 & 0,64 & 16 & 4,51 & 0,73 & 9 & 0,507 \\
\hline Yüzme havuzu & 4,42 & 0,87 & 17 & 4,51 & 0,83 & 10 & 0,528 \\
\hline (algılanan) Parasal değer & 4,41 & 0,70 & 18 & 4,31 & 0,95 & 23 & 0,515 \\
\hline Açık büfe yiyecek çeşitliliği & 4,41 & 0,67 & 19 & 4,49 & 0,74 & 12 & 0,534 \\
\hline Tesisin konumu & 4,41 & 0,64 & 20 & 4,40 & 0,79 & 19 & 0,950 \\
\hline Ortak alanların dekoru & 4,40 & 0,68 & 21 & 4,26 & 0,81 & 26 & 0,297 \\
\hline İyi aydınlatılmış odalar & 4,38 & 0,69 & 22 & 4,37 & 0,85 & 21 & 0,925 \\
\hline Dinlendirici lobi ve bar(lar) & 4,37 & 0,56 & 23 & 4,36 & 0,75 & 22 & 0,911 \\
\hline Odaların dekoru & 4,35 & 0,63 & 24 & 4,29 & 0,74 & 24 & 0,590 \\
\hline Kolay okunabilir menü, işaret ve bilgiler & 4,35 & 0,69 & 25 & 4,06 & 0,97 & 29 & 0,062 \\
\hline Odaların genişliği ve ferahlığı & 4,33 & 0,66 & 26 & 4,42 & 0,71 & 17 & 0,499 \\
\hline İyi aydınlatılmış ortak alanlar & 4,32 & 0,75 & 27 & 4,39 & 0,80 & 20 & 0,624 \\
\hline Otel etrafında kolayca gezinti imkânı & 4,28 & 0,94 & 28 & 4,16 & 0,98 & 28 & 0,486 \\
\hline Uygulanan fiyat & 4,27 & 0,77 & 29 & 4,17 & 0,93 & 27 & 0,505 \\
\hline Erken saatte akşam yemeği olanağı & 4,25 & 0,72 & 30 & 3,82 & 1,22 & 31 & $0,008^{* *}$ \\
\hline Küçük porsiyon yiyecek bulabilme olanağı & 4,20 & 0,81 & 31 & 3,96 & 1,10 & 30 & 0,147 \\
\hline Özel diyet menüleri & 4,09 & 1,007 & 32 & 3,58 & 1,400 & 33 & $0,014^{*}$ \\
\hline İndirimler & 3,98 & 1,022 & 33 & 3,41 & 1,040 & 35 & $0,003^{* *}$ \\
\hline Üst yaş gruplarına yönelik hizmetler & 3,88 & 1,130 & 34 & 3,27 & 1,300 & 36 & $0,006^{* *}$ \\
\hline Jakuzi, sauna & 3,88 & 1,313 & 35 & 3,55 & 1,321 & 34 & 0,163 \\
\hline Tesiste organize edilen eğlenceler & 3,85 & 1,072 & 36 & 3,71 & 1,276 & 32 & 0,505 \\
\hline Jimnastik & 3,55 & 1,396 & 37 & 3,12 & 1,423 & 37 & 0,083 \\
\hline Park yeri & 3,00 & 1,679 & 38 & 2,12 & 1,601 & 38 & $0,005^{\star *}$ \\
\hline
\end{tabular}

${ }^{*} \mathrm{p}<0,05$; ${ }^{* *} \mathrm{p}<0,01$; ÖS: Önem Sıras1 
Yaşlı Turistlerin Otel İşletmelerinde Önem Verdiği Ürün ve Hizmetler: Alman, İngiliz ve Hollandalı Turistlere Yönelik Bir Karşılaştırma

Tablo 5. 50-64 Yaş Arası Katılımcıların Milliyetlerine Göre Önem Karşılaştırması

\begin{tabular}{|c|c|c|c|c|c|}
\hline Ürün ve Hizmetler & $\operatorname{Alman}(A)$ & Hollandalı $(H)$ & Ingiliz (I) & $p$ & Farklar \\
\hline Uygulanan fiyat & 4,34 & 4,17 & 4,49 & $0,011^{*}$ & $\mathrm{H}<\mathrm{i}$ \\
\hline Personelin dış görünümü & 4,59 & 4,40 & 4,51 & $0,036^{*}$ & $A>H$ \\
\hline Personelin dikkati & 4,62 & 4,44 & 4,70 & $0,003^{\star *}$ & $\mathrm{~A}>\mathrm{H}, \mathrm{H}<\mathrm{i}$ \\
\hline İndirimler & 3,75 & 3,41 & 3,84 & $0,009^{* *}$ & $\mathrm{~A}>\mathrm{H}, \mathrm{H}<\mathrm{i}$ \\
\hline Jimnastik & 3,67 & 3,12 & 2,68 & $0,000^{* *}$ & $\mathrm{~A}>\mathrm{H}, \mathrm{H}>\mathrm{I}, \mathrm{A}>\mathrm{I}$ \\
\hline Jakuzi, sauna & 3,75 & 3,55 & 3,19 & $0,000^{* *}$ & $A>i$ \\
\hline Sigara içilmeyen odalar & 4,07 & 4,48 & 4,33 & $0,010^{* *}$ & $\mathrm{~A}<\mathrm{H}$ \\
\hline Tesiste organize edilen eğlenceler & 3,12 & 3,71 & 3,95 & $0,000^{\star *}$ & $\mathrm{~A}<\mathrm{H}, \mathrm{A}<\mathrm{i}$ \\
\hline (algılanan) Parasal değer & 4,59 & 4,31 & 4,70 & $0,000^{* *}$ & $\mathrm{~A}>\mathrm{H}, \mathrm{H}<\mathrm{i}$ \\
\hline İyi aydınlatılmış ortak alanlar & 4,18 & 4,39 & 4,45 & $0,001^{* *}$ & $A<i$ \\
\hline Açık büfe yiyecek çeşitliliği & 4,69 & 4,49 & 4,63 & $0,023^{*}$ & $\mathrm{~A}>\mathrm{H}$ \\
\hline Dinlendirici lobi ve bar(lar) & 4,54 & 4,36 & 4,63 & $0,004^{* *}$ & $\mathrm{~A}>\mathrm{H}, \mathrm{H}<\mathrm{i}$ \\
\hline Yüzme havuzu & 4,32 & 4,51 & 4,58 & $0,003^{* *}$ & $A<i$ \\
\hline Ortak alanların rahatı̆̆ı & 4,43 & 4,51 & 4,69 & $0,000^{* *}$ & $A<i$ \\
\hline Ortak alanların dekoru & 4,33 & 4,26 & 4,48 & $0,016^{*}$ & $\mathrm{H}<\mathrm{i}$ \\
\hline Otel etrafında kolayca gezinti imkânı & 4,54 & 4,16 & 4,15 & $0,000^{* *}$ & $A>H, A>I$ \\
\hline Hizmetlerin yeterliliği & 4,49 & 4,55 & 4,65 & $0,024^{*}$ & $A<i$ \\
\hline Hizmetlerin sunum hızı & 4,49 & 4,50 & 4,69 & $0,001^{* *}$ & $\mathrm{~A}<\mathrm{i}, \mathrm{H}<\mathrm{i}$ \\
\hline Tesisin şöhreti & 3,54 & 4,27 & 4,50 & $0,000^{* *}$ & $\mathrm{~A}<\mathrm{H}, \mathrm{A}<\mathrm{i}$ \\
\hline Güvenlik ve koruma & 4,59 & 4,55 & 4,78 & $0,001^{* *}$ & $\mathrm{~A}<\mathrm{i}, \mathrm{H}<\mathrm{i}$ \\
\hline Küçük porsiyon yiyecek bulabilme olanağı & 3,53 & 3,96 & 3,33 & $0,001^{* *}$ & $\mathrm{~A}<\mathrm{H}, \mathrm{H}>\mathrm{I}$ \\
\hline Özel diyet menüleri & 3,14 & 3,58 & 3,36 & $0,024^{*}$ & $\mathrm{~A}<\mathrm{H}$ \\
\hline
\end{tabular}

${ }^{*} \mathrm{p}<0,05 ;{ }^{* *} \mathrm{p}<0,01$

tistiki açıdan anlamlı farklılık bulunmuştur. 65 yaş ve üzeri Hollandalı katılımcılar "erken saatte akşam yemeği olanağı", "özel diyet menüleri”, "indirimler" ve "üst yaş gruplarına yönelik hizmetler"e 50-64 yaş arasındaki katılımcılara göre daha fazla önem vermektedir. Her iki yaş grubundaki Hollandalı katılımcılar için en az öneme sahip hususlar "özel diyet menüleri", "indirimler", "üst yaş gruplarına yönelik hizmetler", "jakuzi, sauna", "tesiste organize edilen eğlenceler", "jimnastik" ve "park yeri"dir.

\section{Yaş Gruplarına Göre Üç Milliyetin Önem Karşılaştırması}

50-64 yaş grubundaki katılımcıların milliyetlerine bağlı olarak otel işletmelerinin sunduğu ürün ve hizmetlere verdikleri önem arasında istatistiki açıdan farklılık bulunup bulunmadığı tek yön- lü Varyans analizi ile incelenmiş ve sonuçlar Tablo 5 'te gösterilmiştir. Farklılık bulunan değișkenlerde farkların hangi milliyetler arasında olduğunu tespit etmek için grupların örnek sayıları birbirinden farklı olması sebebiyle Scheffe testinden faydalanılmıştır.

50-64 yaş aralığındaki Hollandalı katılımcılar "personelin dikkati", "indirimler", "(algılanan) parasal değer" ve "dinlendirici lobi ve bar(lar)" hususlarına Alman ve İngiliz katılımcılara göre daha az; "küçük porsiyon yiyecek bulabilme olanağı"na ise daha fazla önem vermektedirler. Alman kat1lımcılar için "tesiste organize edilen eğlenceler" ve "tesisin şöhreti", Hollandalı ve İngiliz katılımcılara göre daha az; "otel etrafında kolayca gezinti imkânı" daha fazla önemli olan hususlardır. "İyi aydınlatılmış ortak alanlar", "yüzme havuzu”, "ortak alanların rahatlığı" ve "hizmetlerin yeterliliğii" 
Tahir Albayrak - Meltem Caber - Müjde Bideci

Tablo 6. 65 Yaş ve Üzeri Katılımcıların Milliyetlerine Göre Önem Karşılaştırması

\begin{tabular}{llllll}
\hline Ürün ve Hizmetler & Alman $(A)$ & Hollandalı $(H)$ & Ingiliz $(i)$ & $p$ & Farklar \\
\hline Personelin dış görünümü & 4,69 & 4,43 & 4,73 & $0,011^{*}$ & $\mathrm{~A}>\mathrm{H}, \mathrm{H}<\mathrm{i}$ \\
\hline Jimnastik & 3,68 & 3,55 & 3,13 & $0,006^{* *}$ & $\mathrm{~A}>\mathrm{i}$ \\
\hline Tesiste organize edilen eğlenceler & 3,53 & 3,85 & 4,19 & $0,000^{* *}$ & $\mathrm{~A}<\mathrm{i}$ \\
\hline (algılanan) Parasal değer & 4,68 & 4,41 & 4,82 & $0,000^{* *}$ & $\mathrm{~A}>\mathrm{H}, \mathrm{H}<\mathrm{i}$ \\
\hline Iyi aydınlatılmış ortak alanlar & 4,18 & 4,32 & 4,63 & $0,000^{* *}$ & $\mathrm{~A}<\mathrm{i}$ \\
\hline Açık büfe yiyecek çeşitliliği & 4,71 & 4,41 & 4,65 & $0,014^{*}$ & $\mathrm{~A}>\mathrm{H}$ \\
\hline Dinlendirici lobi ve bar(lar) & 4,37 & 4,37 & 4,69 & $0,003^{* *}$ & $\mathrm{~A}<\mathrm{i}$ \\
\hline Genel temizlik & 4,81 & 4,60 & 4,93 & $0,000^{* *}$ & $\mathrm{~A}>\mathrm{H}, \mathrm{H}<\mathrm{i}$ \\
\hline Odaların rahatlığı & 4,66 & 4,67 & 4,86 & $0,006^{* *}$ & $\mathrm{~A}<\mathrm{i}$ \\
\hline Ortak alanların rahatlığı & 4,49 & 4,43 & 4,72 & $0,005^{* *}$ & $\mathrm{~A}<\mathrm{i}, \mathrm{H}<\mathrm{i}$ \\
\hline Ortak alanların dekoru & 4,43 & 4,40 & 4,64 & $0,019^{*}$ & $\mathrm{~A}<\mathrm{i}$ \\
\hline Otel etrafında kolayca gezinti imkânı & 4,59 & 4,28 & 4,54 & $0,026^{*}$ & $\mathrm{~A}>\mathrm{H}$ \\
\hline Hizmetlerin yeterliliği & 4,54 & 4,58 & 4,79 & $0,002^{* *}$ & $\mathrm{~A}<\mathrm{i}$ \\
\hline Personelin kibarlığı & 4,75 & 4,58 & 4,86 & $0,012^{*}$ & $\mathrm{H}<\mathrm{i}$ \\
\hline Hizmetlerin sunum hızı & 4,51 & 4,60 & 4,77 & $0,003^{* *}$ & $\mathrm{~A}<\mathrm{i}$ \\
\hline Tesisin şöhreti & 3,89 & 4,53 & 4,73 & $0,000^{* *}$ & $\mathrm{~A}<\mathrm{H}, \mathrm{A}<\mathrm{i}$ \\
\hline Odaların genişliği ve ferahlığı & 4,62 & 4,33 & 4,63 & $0,026^{*}$ & $\mathrm{~A}>\mathrm{H}, \mathrm{H}<\mathrm{i}$ \\
\hline Küçük porsiyon yiyecek bulabilme olanağı & 3,69 & 4,20 & 3,59 & $0,038^{*}$ & $\mathrm{H}>\mathrm{i}$ \\
\hline Özel diyet menüleri & 3,35 & 4,09 & 3,79 & $0,002^{* *}$ & $\mathrm{~A}<\mathrm{H}, \mathrm{A}<\mathrm{i}$ \\
\hline Otelin bakım/onarım standartları & 4,59 & 4,57 & 4,83 & $0,000^{* *}$ & $\mathrm{~A}<\mathrm{i}, \mathrm{H}<\mathrm{i}$ \\
\hline P & & & & \\
\hline
\end{tabular}

${ }^{*} \mathrm{p}<0,05 ;{ }^{* *} \mathrm{p}<0,01$

İngiliz katılımcılar açısından Alman katılımcılara göre daha önemlidir. Buna karşılık "jakuzi, sauna", İngiliz katılımcılarla kıyaslandı̆̆ında Alman katılımcilar açısından daha önemli bir husustur. Tablo 5 'te hangi milliyetler arasında önem farklılığı bulunduğu detaylı olarak gösterilmiştir.

İzleyen aşamada, 65 yaş ve üzeri katılımcıların otel işletmelerinin sunduğu ürün ve hizmetlere vermiş oldukları önem arasında milliyetlerine göre farkl1liklar tek yönlü Varyans analizi ile test edilmiştir. Farkların hangi milliyetler arasında olduğunu tespit etmek maksadiyla Scheffe testinden faydalanılmış ve aralarında istatistiki açıdan anlamlı önem farklılıkları bulunan hususlar Tablo 6'da gösterilmiştir. 65 yaş ve üzeri Hollandalı katılımcılar, İngiliz ve Alman katılımcılara kıyasla "personelin diş görünümü", "(algılanan) parasal değer", "genel temizlik" ve "odaların genişliği ve ferahlığı" na daha fazla önem vermektedir. "Tesisin şöhreti" ve "özel diyet menüleri" 65 yaş ve üzeri Alman katılımcılar için diğer milliyetlere göre da- ha az önemliyken, 65 yaş ve üzeri İngiliz katılımcılar açısından "otelin bakım/onarım standartları" ve "ortak alanların rahatlığı" diğer milliyetlere göre daha önemlidir. Ayrıca, 65 yaş ve üzeri İngiliz katılımcılar "tesiste organize edilen eğlenceler", "iyi aydınlatılmış ortak alanlar", "dinlendirici lobi ve bar(lar)", "odaların rahatllğı", "ortak alanlarin dekoru", "hizmetlerin yeterliliği", "hizmetlerin sunum hızı"na Almanlara kıyasla daha fazla önem verirken, "jimnastik"e daha düşük önem vermektedir.

\section{SONUÇ VE ÖNERILER}

Bu çalışmada, yaşlı turistlerin otel işletmelerinde kendilerine sunulan ürün ve hizmetlere verdikleri önem tespit edilmeye çalışılmıştır. İlgili çalışmanın benzer çalışmalardan en önemli farklılığı, araştırmanın gerçekleştirildiği Antalya bölgesi için en önemli üç yaşlı pazar bölümüne aynı anda odaklanması ve yaşlı turistleri iki alt yaş grubuna (50-64 yaş arası; 65 yaş ve üzeri) ayırarak ürün ve hizmet- 
lere verdikleri önemi her grup için ayrı ayrı incelemesidir. Alanyazına yönelik başlıca katkısı ise her milliyet için yaş gruplarına göre önem farklarını karşılaştırarak, yaşlı turistlerin de kendi içinde otel ürün ve hizmetlerine verdikleri önem bakımından farklılık gösterip göstermediğini araştırmış olmasıdır. Ayrıca her yaş grubu için araştırmaya dahil edilen üç milliyetin sunulan ürün ve hizmetlere verdikleri önemin değişip değişmediğinin de araştırılmış olması, yaşlı turist pazarının daha yakından tanınmasına önemli katkı sağlamıştır.

Araştırmanın yaşlı turistleri hedeflemesinin doğal bir sonucu olarak, üç milliyet için 65 yaş ve üzeri katılımcıların \%80'den fazlasının emeklilerden oluştuğu tespit edilmiştir. Her iki yaş grubundaki Alman ve Hollandalı turistlerin \%70'den fazla kesiminin Türkiye'ye 4 ve daha çok kez gelmiş olması, buna karşılık İngilizlerde bu oranın sadece \%39 olması önemli bir bulgudur. Her iki yaş grubundaki İngiliz katılımcıların ağırlıklı olarak 1-7 gün arası konaklama süresini tercih ettikleri tespit edilmiştir. Bu bulgu, yaşlı İngilizlerin ortalama konaklama süresinin beş gün olarak tespit edilmiş olduğu Callan ve Bowman'ın (2000) çalışması ile benzerlik taşımaktadır. Daha önce gerçekleştirilen birçok çalişmada (Badinelli, Davis ve Gustin 1991; Callan ve Bowman 2000) olduğu gibi "temizlik" tüm yaşlı grupları için (65 yaş ve üzeri Hollandalı katılımcılar hariç) en önemli husus olarak tespit edilmiştir. Bu bulgu temel hususların önceliğine bir kez daha vurgu yapmaktadır. Önceki çalışmalarda olduğu gibi (Mohsin ve Lockyer 2009), bu çalışmada da personelin tutum ve davranışlarına yüksek önem verildiğinin tespit edilmiş olması, hizmet işletmelerinde çalışan personele yönelik içsel pazarlamanın önemini göstermektedir. Her iki yaşlı grubundaki Alman katılımcılar için tesisin şöhreti önem taşımaz iken otel etrafında gezinti imkânı diğer milliyetlere göre daha fazla öneme sahiptir. Bu sonuç yaşlı Almanların sadece otelin içinde vakit geçirmek istemedikleri, yakın çevreyi de tanımak istedikleri şeklinde yorumlanabilir. Bir diğer önemli bulgu ise 65 yaş ve üzeri Hollandalı turistlerin sağlıklı beslenmeye, aynı yaş grubundaki İngiliz ve Alman turistlere göre daha fazla önem vermekte olduğudur. "Algılanan değer" İngiliz katılımc1ların 65 yaş ve üzeri grubunda beşinci, 50-64 yaş grubunda ise altıncı önemli özellik olarak tespit edilmiştir. Bu bulgu İngilizler için algılanan değeri önemli bulan Callan ve Bowman'ın (2000) sonuçlarinı desteklemektedir.

Yapılan alan araştırması sonucunda, 50-64 yaş arası ile 65 yaş ve üzeri Alman, İngiliz ve Hollandalı turistlerin, otel işletmelerinin sunmuş oldukları çeşitli ürün ve hizmetlere, farklı derecede önem verdikleri tespit edilmiştir. Elde edilen bu sonuç, araştırmanın amaçlarından biri olan farklı yaş grupları arasında karşılaştırma yapabilmenin ne derece önemli bir konu olduğunu ve müşteri beklentilerinin buna bağlı olarak değişebildiğini göstermektedir. Bu nedenle işletmelerin farklı yaş gruplarındaki müşterilerine hitap edebilmeleri ve müşteri beklentilerini karşılayabilmesi için müşteri odaklı bir yapı kazanarak, yenilikçi ürün ve hizmetler geliştirebilmeleri gerekmektedir.

Turizm işletmeleri, 2050 yılına kadar gerçekleşmesi beklenen dünya nüfus yapısındaki değişimlerden etkilenecektir. Nüfus yapısındaki değişimlerden biri toplam nüfus içinde yaşlıların oranının artacak olmasıdır. Buna paralel olarak yaşlı turistlerin farklı ihtiyaç ve beklentilerinin tespit edilmesi, turizm işletmeleri açısından önem taşıyan bir araştırma alanı olacaktır. Rakip işletmeler karşısında üstünlük sağlanabilmesi için, yaşlı turistlerin otel işletmelerindeki ürün ve hizmetlerden memnun kalmaları sağlanmalıdır. Bu nedenle yaşlıların otellerde önem verdikleri hususların ortaya konularak, demografik özelliklerle ilişkilerinin incelenmesi, pazar bölümleri arasındaki benzer ve farklı özelliklerin anlaşılması gerekmektedir.

Bu çalışma, gerek kapsam genişliği gerekse elde edilmiş olan bulguların faydası açısından ilgili alanyazına önemli bir katkı sağlamıştır. Ancak bir takım kısıtları da bulunmaktadır. Çalışmanın başlıca kısıtı, alan araştırmasının Antalya ili Kundu mevkii ve Finike ilçesi ile sınırlı olmasıdır. Bu yörelerde faaliyet gösteren beş yıldızlı otellerde üç milliyetten müşterinin katılımı ile elde edilmiş olan sonuçların, Türkiye'ye gelen yabancı yaşlı turistler için genellenebilmesi söz konusu değildir. Bu nedenle ileride gerçekleştirilecek olan çalışmalarda, akademisyenlerin coğrafik açıdan daha yaygın ve daha fazla örneklem çeşitliliğine sahip araştırmalar yapmaları önerilebilir. Ayrıca orijinali İngilizce olan ölçeğin (Callan ve Bowman, 2000) Almanca'ya profesyonel bir tercüman tarafından çevrilmesinin ardindan, anadili Almanca olan bir otel rehberleri tarafından kontrol edilmesi; buna karşılık geri ter- 
cüme yapılmaması çalışmanın diğer kısıtı olarak değerlendirilebilir. Son olarak, özelliklerin öneminin 5 'li ölçek ile ölçülmüş olması sebebiyle verilerin dağılımı normallik testleri yerine, görsel olarak tespit edilmiştir.

\section{BíLGILENDIRME}

Bu çalışma Akdeniz Üniversitesi Bilimsel Araştırma Projeleri Koordinasyon Birimi tarafından desteklenmiştir. Proje numarası 2011.01.0131.001.

\section{KAYNAKÇA}

Alegre, J., Cladera, M. ve Sard, M. (2011). Analysing the Influence of Tourist Motivations on Tourist Expenditure at a Sun-and-Sand Destination, Tourism Economics, 17 (4): 813-832.

Avcıkurt, C. (2003). The Mature Age Market in Europe and its Influence on Tourism, Balkesir Üniversitesi Sosyal Bilimler Dergisi, 6 (9): 141-157.

Badinelli, K., Davis, N. ve Gustin, L. (1991). Senior Travel Study, Hotel and Motel Management, 206: 31-34.

Batra, A. (2009). Senior Pleasure Tourists: Examination of Their Demography, Travel Experience, and Travel Behavior upon Visiting the Bangkok Metropolis, International Journal of Hospitality $\mathcal{E}$ Tourism Administration, 10: 197-212.

Callan, R. J. ve Bowman, L. (2000). Selecting a Hotel and Determining Salient Quality Attributes: A Preliminary Study of Mature British Travellers, International Journal of Tourism Research, 2: 97-118.

Chen, K-H., Liu, H-H. ve Chang, F-H. (2013). Essential Customer Service Factors and the Segmentation of Older Visitors within Wellness Tourism based on Hot Springs Hotels, International Journal of Hospitality Management, 35: 122-132.

Chu, R.K.S. ve Choi, T. (2000). An Importance-Performance Analysis of Hotel Selection Factors in the Hong Kong Hotel Industry: A Comparison of Business and Leisure Travellers, Tourism Management, 21: 363-377.

Esichaikul, R. (2012). Travel Motivations, Behavior and Requirements of European Senior Tourists to Thailand, PASOS: Revista de Turismo y Patrimonio Cultural, 10 (2): 47-58.

Fleischer, A. ve Pizam, A. (2002). Tourism Constraints among Israeli Seniors, Annals of Tourism Research, 29: 106-123.

Gram, M. ve Smed, K.M. (2011). We can Dink Our Coffee More Slowly. Discursive Uses of Age in Relation to Holiday Consumption - Examples among Danish and German Mature Travellers, e-Journal of Applied Psychology: Clinical and Social Issues, 7 (1): 2-7.

Gustin, M. E. ve Weaver, P. A. (1993). The Mature Market: Underlying Dimensions and Group Differences of a Potential Market for the Hotel Industry, FIU Hospitality Review, 11 (2): 45-59.

Güler, Ç. (1998). Yaşlılıkta Tanımlar ve Yaşlılık Üstüne Söylenenler, Geriatri- Turkish Journal of Geriatrics, 1 (2): 105.

Hartman, J. D. ve Qu, H. (2007). The Senior Travel Market: Do's and Don'ts, Journal of Quality Assurance in Hospitality $\mathcal{E}$ Tourism, 8 (2): 67-81.

Horneman, L., Carter, W.R, Wei, S. ve Ruys, H. (2002). Profiling the Senior Traveler: An Australian Perspective, Journal of Travel Research, 41: 23-37.
Hudson, S. (2010). Wooing Zoomers: Marketing to the Mature Traveler, Marketing Intelligence \& Planning, 28 (4): 444-461.

Hunter-Jones, P. ve Blackburn, A. (2007). Understanding the Relationship Between Holiday Taking and Self-assessed Helath: An Exploratory Study of Senior Tourism, International Journal of Consumer Studies, 31: 509-516.

Jang, S-C. (Shawn) ve Wu, C-M.E. (2006). Seniors' Travel Motivation and the Influential Factors: An Examination of Taiwanese Seniors, Tourism Management, 27: 306-316.

Jang, S. C. (Shawn) ve Ham, S. (2009). A Double-Hurdle Analysis of Travel Expenditure: Baby Boomer Seniors versus Older Seniors, Tourism Management, 30: 372-380.

Jang, S. C. (Shawn), Bai, B., Hu, C., Mei, C. ve Wu, E. (2009). Affect, Travel Motivation, and Travel Intention: A Senior Market, Journal of Hospitality \& Tourism Research, 33: 51-73.

Javalgi, R. G., Thomas, E. G. ve Rao, S. R. (1992). Consumer Behaviour in the US Pleasure Travel Marketplace: An Analysis of Senior and Nonsenior Travellers, Journal of Travel Research, 31: 14-19.

Kim, Y-S., Raab, C. ve Bergman, C. (2010). Restaurant Selection Preferences of Mature Tourists in Las Vegas: A Pilot Study, International Journal of Hospitality \& Tourism Administration, 11 (2): 157-170.

Kim, Y-S., Bergman, C. ve Raab, C. (2010). Factors That Impact Mature Customer Dining Choices in Las Vegas, Journal of Food Service Business Research, 13 (3): 178-192.

Kotler, P., Bowen, J. ve Makens, J. (1996). Marketing for Hospitality and Tourism. Upper Saddle River, NJ: Prentice Hall.

Lee, T. J., Cho, H. ve Ahn, T-H. (2012). Senior Citizen Satisfaction with Restaurant Service Quality, Journal of Hospitality Marketing \& Management, 21 (2): 215-226.

Lee, L. Y-S., Tsai, H. ve Tsang, N. K. F. (2012). Selection of Outbound Package Tours: The Case of Senior Citizens in Hong Kong, Journal of China Tourism Research, Special Issue: Chinese Consumer Behaviors and Psychology in Tourism Settings, 8 (4): 450-468.

Lewis, H. G. (1996). Another Look at the Seniors Market, Direct Marketing, Mart 1: 20-23.

Littrell, M. A., Paige, R. C. ve Song, K. (2004). Senior Travellers: Tourism Activities and Shopping Behaviours, Journal of Vacation Marketing, 10 (4): 348-362.

Marvel, M. (1999). Competing in Hotel Services For Seniors, International Journal of Hospitality Management, 18 (3): 235-243.

Mohsin, A. ve Lockyer, T.(2009). Customer Perceptions of Service Quality in Luxury Hotels in New Delhi, India: An Exploratory Study, International Journal of Contemporary Hospitality Management, 22 (2): 160-173.

Mungall, A., Schegg, R. ve Courvoisier, F. (2010). Exploring Communication and Marketing Strategies for Senior Travelers, İçinde Joseph S. Chen Var (Editor) Advances in Hospitality and Leisure (ss. 6: 59-82). Emerald Group Publishing Limited.

Özdipçiner, S. N. (2009). A Study of Travel Satisfaction on Elderly German Travelers to Bodrum, Pakistan Journal of Social Sciences, 6 (5): 268-276.

Özdipçiner, S. N. (2010). Yaşlı Alman Turistlerin Tatil Tatmini: Hastalık ve Çalışma Durumlarına İlişkin Bir Araştırma, International Journal of Economic and Administrative Studies, 2 (4): $25-40$.

Patterson, I. (2007). Information Sources Used by Older Adults for Decision Making about Tourist and Travel Destinations, InternationalJournal of Consumer Studies, 31 (5): 528-533. 
Reece, W. S. (2004). Are Senior Leisure Travelers Different?, Journal of Travel Research, 43: 11-18.

Riley, M. W. ve Riley, J. (1986). Longevity and Social Structure: The Potential of the Added Years, (A.Pifer ve L.Bonte (Ed.), Our Aging Society: Paradox and Promise, New York: NY. W.W. Norton.

Sangpikul, A. (2008a). Travel Motivations of Japanese Senior Travellers to Thailand, International Journal of Tourism Research, 10: 81-94.

Sangpikul, A. (2008b). A Factor-Cluster Analysis of Tourist Motivations: A Case of U.S. Senior Travellers, Tourism, 56 (1): 23-40.

Schitko, D. ve Losekoot, E. (2012). An Investigation of the Attitudes of Travel and Tourism Intermediaries to Mature Travellers, Journal of Tourism, 13 (1): 61-78.

Seyhun, Ö. K. (2006). Avrupa Birliği'ndeki Demografik Dönüşümün Türkiye'nin Avrupa Birliği'ne Üyeliği Çerçevesinde İş Gücü Piyasalarına Yansıması, Türkiye Cumhuriyet Merkez Bankası Dış İlişkiler Genel Müdürlüğü, Uzmanlık Yeterlilik Tezi, 1-101.

Shoemaker, S. (1989). Segmentation of the Senior Pleasure Travel Market, Journal of Travel Research, 27: 14-21.

Shortt, G. ve Ruys, H. (1994). Hotel Security: The Needs of the Mature Age Market, International Journal of Contemporary Hospitality Management, 6 (5): 14-19.
Silvers, C. (1997). Smashing Old Stereotypes of 50-plus America, Journal of Consumer Marketing, 14: 303-309.

Śniadek, J. (2006). Age of Seniors- A Challenge for Tourism and Leisure Industry, Studies in Physical Culture and Tourism, 13: 103-105.

Tümerdem, Y. (2006). Gerçek Yaș, Geriatri- Turkish Journal of Geriatrics, 9 (3): 195.

Wang, K. C., Chen, J., S. ve Chou, S. H. (2007). Senior Tourists' Purchasing Decisions in Group Package Tour, Anatolia: An International Journal of Tourism and Hospitality Research, 18 (1): 23-42.

Wei, S., Ruys, H. ve Muller, T. E. (1999). A Gap Analysis of Perceptions of Hotel Attributes by Marketing Managers and Older People in Australia, Journal of Marketing Practice: Applied Marketing Science, 5 (6/7/8): 200-212.

WHO (World Health Organisation), (2013). http://www.who.int/ ageing/en/, Erişim tarihi: 16.05.2013.

Wuest, B., Emenheiser, D. ve Tas, R. R. (2001). Is the Lodging Serving the Needs of Mature Consumers? A Comparison of Mature Travelers' and Lodging Managers' Perceptions of Service Needs?, Journal of Hospitality \& Leisure Marketing, $8(3 / 4): 85-96$. 